\author{
ALEKSANDER CIEŚLIŃSKI \\ ORCID: 0000-0001-7459-564X \\ Uniwersytet Wrocławski \\ Katedra Prawa Europejskiego i Międzynarodowego
}

\title{
MODELE AUTOMATYCZNEGO UZNAWANIA KWALIFIKACJI ZAWODOWYCH W UNII EUROPEJSKIEJ I ICH WDROŻENIE W POLSKIM PORZĄDKU PRAWNYM
}

\begin{abstract}
Abstrakt: Założeniem niniejszego artykułu jest analiza realizacji regulacyjnej wzajemnej uznawalności w szczególnym obszarze uznawania kwalifikacji zawodowych w Unii Europejskiej — zarówno na poziomie ponadnarodowym, jak i krajowym. Pozwala to bowiem przedstawić ogólniejsze prawidłowości funkcjonowania jednolitego rynku wewnętrznego i realizacji jego swobód, szczególnie osobowych, a więc problematykę podziału władzy nie tylko pomiędzy samymi państwami członkowskimi (pochodzenia) i przyjmującym, lecz także państwami a Unią. W tym celu dokonano wyboru jednego z obowiązujących modeli uznawalności — automatycznego, gdyż jest to przejaw najdalej idącej ingerencji regulacyjnej z poziomu ponadnarodowego. Przedmiotem analizy stało się samo rozumienie uznawania w zawodach regulowanych, a także systematyka prawa - w tym względzie wykorzystano regulacje obowiązujące w Polsce jako przykład krajowego wysiłku implementacyjnego. Szczególny nacisk położono na przedstawienie specyficznego charakteru uznawania w zawodach medycznych, jak też tak zwanych wspólnych ram kształcenia oraz uznawania doświadczenia zawodowego.
\end{abstract}

Słowa kluczowe: zasada wzajemnej uznawalności, uznawanie kwalifikacji zawodowych, dyrektywa 2005/36, zawody sektorowe, wspólne ramy kształcenia

\section{WYZWANIA WZJEMNEJ UZNAWALNOŚCI KWALIFIKACJI ZAWODOWYCH}

Swobodny przepływ profesjonalistów w Unii Europejskiej ma ogromne znaczenie dla funkcjonowania jednolitego rynku wewnętrznego, lecz jego zapewnienie okazało się wyzwaniem nawet na tle innych aspektów integracji gospodarczej. Państwa członkowskie zachowały znaczne kompetencje w zakresie regulacji swoich rynków i przede wszystkim systemów kształcenia, a dostęp do najważniejszych zawodów z zasady obwarowany jest licznymi warunkami. W wielu przypadkach, podyktowane nawet obiektywnie słusznymi względami ochrony bezpieczeństwa 
obrotu wymogi kwalifikacyjne, funkcjonujące obok siebie w ramach różnych reżimów krajowych, były istotną przeszkodą w takim swobodnym przepływie. Dotyczy to szczególnie sytuacji, gdy aktywność transgraniczna obciążona zostaje ciężarem sprostania wymogom prawnym zarówno państwa pochodzenia, jak i przyjmującego. Część z nich mogła mieć wymiar materialny związany z inną treścią, charakterem, a nawet poziomem kształcenia, pozostałe czysto formalny — dotyczący odmienności dokumentów czy instytucji je wydających ${ }^{1}$.

Należy przypomnieć, że system rynku wewnętrznego wypracował metody „zarządzania” różnicami regulacyjnymi pomiędzy systemami krajowymi, określane jako integracja negatywna - związana z jedną z najważniejszych dla Unii zasad wzajemnej uznawalności — oraz pozytywna, opierająca się na harmonizacji i przyjmowaniu wspólnych standardów. Wzajemna uznawalność kojarzona jest z samoistnym stosowaniem bezpośrednio skutecznych przepisów traktatowych, gwarantujących swobodny przepływ, często poddanych nader kreatywnej wykładni w celu rozwiązania nawet bardzo konkretnych sporów bez konieczności odwoływania się do norm szczególnych unijnego prawa pochodnego. Ma to ułatwiać znoszenie pomiędzy państwami wszelkich barier, które utrudniają aktywność transgraniczną, w imię otwartości ich rynków, nawet jeżeli na przykład usługodawcy nie spełniają lokalnych wymogów, co normalnie skutkuje uznaniem ich działalności za bezprawną. W tym celu usankcjonowano uznawanie „wytworów” obcych reżimów regulacyjnych, nawet jeżeli opierają się one na odmiennych standardach, jako mających status ekwiwalentny wobec miejscowych i zdolnych do uczestnictwa w obrocie krajowym, o ile nie zachodzą szczególne okoliczności potwierdzające zagrożenie dla interesu ogólnego ${ }^{2}$.

Tradycyjnie daje to asumpt do rozstrzygnięć o podziale kompetencji regulacyjnej krajowych prawodawców czy też kontroli nad rynkiem - pomiędzy państwem przyjmującym, którego reżim powinien niejako ustąpić temu macierzystemu. Dlatego też zasada ta bywa nawet identyfikowana z tak zwaną regułą kraju pochodzenia, którego system miałby ostatecznie przeważać, wymuszając w obrocie transgranicznym akceptację między innymi profesjonalistów wykwalifikowanych zgodnie ze standardami państwa pochodzenia przez wszystkie pozostałe. Klarowność takiego podziału oraz zapobieganie podwójnym obciążeniom i kontroli czyni to atrakcyjnym, a jednocześnie — ze względu na swoją bezwarunkowość - nierealistycznym, skoro system unijny nie wyklucza całkowicie decyzji państwa przyjmującego o stopniu ochrony interesu publicznego na swoim terytorium, egzekwowaniu swoich wymogów, a nawet narzucaniu poddania się lokalnym procedurom dopuszczania pomimo spełnienia reguł kraju pochodzenia.

${ }^{1} \mathrm{M}$. Szwarc, Modele regulacji rynku wewnętrznego — integracja negatywna i pozytywna, [w:] System Prawa Unii Europejskiej, t. 7. Prawo rynku wewnętrznego, red. D. Kornobis-Romanowska, Warszawa 2020, s. 98.

2 M. Górka, Zasada wzajemnego uznawania w prawie Unii Europejskiej, Warszawa 2014, s. 3-4; M. Szwarc, op. cit., s. 96-97. 
Jeżeli jednak odbywa się to wyłącznie na podstawie ogólnych gwarancji traktatowych, które mogą podlegać zróżnicowanej interpretacji, to trudno zapewnić niezbędne poczucie pewności i przewidywalności ${ }^{3}$.

Jak się okazało, złożoność materii uznawania kwalifikacji nie pozwoliła na zapewnienie owego swobodnego przepływu profesjonalistów, jedynie opierając się na przytoczonej zasadzie, tym bardziej w świetle niechęci państw do otwierania swoich rynków i dopuszczania obywateli UE do działalności regulowanej. Działo się tak, nawet jeżeli Trybunał Sprawiedliwości zakwalifikował prawo do takiego uznania jako integralny element gwarancji rynku wewnętrznego, nakazując uwzględnianie zagranicznych dokumentów potwierdzających posiadanie uprawnień zawodowych i stosownego przygotowania w tym zakresie w ocenie zdolności do podejmowania aktywności ekonomicznej. Niezbędne stało się więc przyjmowanie przepisów zapewniających realizację samego prawa, a także podział kompetencji pomiędzy krajowymi reżimami regulacyjnymi ${ }^{4}$.

Harmonizację w klasycznym ujęciu przeciwstawia się wzajemnej uznawalności i traktuje jako odpowiedź na jej niedostatki czy porażki. Niewątpliwie przyjęcie wspólnych reguł na poziomie unijnym, eliminując różnice, rozwiązuje wskazane dylematy, nawet jeżeli nie dochodzi do unifikacji, a jedynie zbliżania ustawodawstw. Jednakże im bardziej unijny prawodawca stara się zastępować krajowych, narzucając im swoje standardy, tym większym problemem się to staje — zarówno w wymiarze politycznym, ze względu na ingerencję poziomu ponadnarodowego w specyfikę obrotu krajowego, jak i czysto regulacyjnym, zważywszy na to, jak trudno jest przyjmować rozwiązania adekwatne dla każdego rynku krajowego. Uznawanie kwalifikacji jest obszarem, w którym wyzwania te ujawniają się ze szczególną intensywnością, biorąc pod uwagę, jak wiele zawodów podlega bardzo szczegółowym, ale zróżnicowanym terytorialnie, regulacjom usankcjonowanym tradycją. Dodatkowo wrażliwość problematyki tylko wzmaga spory o podział władzy5.

${ }^{3}$ I. Kawka, Gospodarcza działalność ustugowa w prawie polskim w świetle unijnych swobód przedsiębiorczości i świadczenia ustug, Warszawa 2015, s. 313-317; M. Górka, op. cit., s. 18 n.; K.A. Armstrong, Mutual recognition, [w:] The Law of the Single European Market. Unpacking the Premises, red. C. Barnard, J. Scott, Hart 2002, s. 229.

${ }^{4}$ I. Vlassopoulou v Ministerium für Justiz, Bundes- und Europaangelegenheiten Baden-Württemberg, C-340/89, ECLI:EU:C:1991:193; R. Torres, The European recognition of professional qualifications - a legal framework for the European citizenship, „EU Law Journal” 2, 2016, nr 2, s. 71-81; E. Skibińska, Analiza orzecznictwa Trybunału Sprawiedliwości Unii Europejskiej dotyczacego wzajemnego uznawania dyplomów, świadectw i innych dokumentów potwierdzajacych posiadane kwalifikacje, [w:] Prawne aspekty porównywania i uznawania kwalifikacji w Unii Europejskiej, red. M. Ponikowska, Warszawa 2015, s. 45-67; E. Skrzydło-Tefelska, Swobodny przepływ osób a wykonywanie zawodu notariusza, „Rejent” 2000, nr 10, s. 173-175; R. Janas, Wzajemne uznawanie dyplomów, [w:] Unia Europejska. Prawo instytucjonalne i gospodarcze, red. A. Łazowski, Warszawa 2007, s. 924.

${ }^{5} \mathrm{~S}$. Weatherill, Pre-emption, harmonisation and the distribution of competence to regulate the internal market, [w:] The Law..., s. 43; M. Szwarz, op. cit., s. 97. 
Współczesna harmonizacja nie musi już jednak polegać tylko na zastępowaniu krajowego ustawodawcy w ustanawianiu standardów obrotu, a więc niekoniecznie przeciwstawia się mechanizmom integracji negatywnej. Wzajemne uznawanie w sferze zharmonizowanej, określane mianem regulacyjnego, względnie legislacyjnego, było jednym z remediów na problemy generowane przez klasyczne podejście do regulacji, praktykowane zwłaszcza w latach siedemdziesiątych — harmonizację pełną, opierającą się na szczegółowych i wyczerpujących przepisach, które w analizowanym obszarze wyjątkowo trudno opracować. Tutaj możliwe jest pozostawienie państwom znacznej autonomii, ale i określenie zakresu dopuszczalnej regulacji, szczególnie po stronie kraju pochodzenia — skutecznej jednak poza jego granicami, a także sprecyzowanie zakresu kontroli państwa przyjmującego nad dopuszczaniem do obrotu na swoim rynku krajowym. Równocześnie eliminuje to niepewność oraz zapewnia bardziej przewidywalne procedury6.

Właśnie takie rozwiązania udało się wypracować w analizowanym zakresie, a ich bardzo zróżnicowana postać jest interesującym przedmiotem badań. Można tu bowiem spotkać zarówno przypadki niemalże bezwarunkowej akceptacji kwalifikacji wynikających z wykształcenia i szkolenia w kraju pochodzenia, jak i bardziej warunkowej, z zachowaniem przez państwo przyjmujące kompetencji do ich weryfikacji i nawet wymuszania pewnego dostosowania się do miejscowych reguł. W tych ramach szczególnie interesujący wydaje się przypadek pierwszy, identyfikowany z modelami automatycznymi - w największym stopniu stara się on bowiem nie tylko godzić z sobą interesy obu zaangażowanych państw, bardziej w duchu reguły kraju pochodzenia, lecz także równoważyć to jeszcze niezbędną w takim kontekście dawką harmonizacji standardów kształcenia. Stanowi zatem adekwatny przykład zarówno horyzontalnego (pomiędzy reżimami krajowymi), jak i wertykalnego (Unia-państwa członkowskie) podziału władzy ${ }^{7}$.

\section{RYNKOWE ROZUMIENIE UZNANIA}

Samo „uznanie” można przedstawiać jako szczególny, indywidualny akt urzędowy, w którym uprawniony organ potwierdza wartość kształcenia czy też przygotowania zawodowego zdobytego w systemie obcym i sankcjonuje jego konse-

${ }^{6}$ P.J. Slot, Harmonisation, „European Law Review” 1996, nr 5, s. 386; M. Möstl, Preconditions and limits of mutual recognition, „Common Market Law Review” 2010, nr 2, s. 415-416; M. Górka, op. cit., s. 16; J. Osiejewicz, Harmonizacja prawa państw członkowskich Unii Europejskiej, Warszawa 2016, s. 58 n.

${ }^{7}$ K. Nicolaïdis, Globalization with human faces: Managed mutual recognition and the free movement of professionals, [w:] The Principle of Mutual Recognition in the European Integration Process, red. F. Kostoris Padoa-Schioppa, Rome 2005, s. 133; B. Blitz, Professional mobility and the mutual recognition of qualifications in the European Union: Two institutional approaches, „Comparative Education Review” 1999, nr 43, s. 312. 
kwencje. Przedmiotem niniejszych analiz nie jest jednak uznanie dla celów akademickich, w których kompetencje UE oraz znaczenie dla swobodnego przepływu są ograniczone. Intensywnej harmonizacji podlega odgrywające w tym kontekście kluczową rolę tak zwane uznanie zawodowe, które umożliwia wykonywanie określonego zawodu na takich zasadach jak miejscowi profesjonaliści. To mające wymiar regulacyjny uznanie określa się mianem uznania de iure - jako przeciwieństwo de facto, w którym decyzja należy do pracodawcy ${ }^{8}$.

Uznanie de iure jest nieodłącznie związane z tak zwanymi zawodami regulowanymi, w ramach których warunki dostępu i wykonywania zawodu, tak jak jego organizacja i zasady uzyskiwania kwalifikacji, podlegają ściślejszej regulacji, a nawet reglamentacji; w wypadku których nie zawsze wystarcza nawet uzyskanie dyplomu uczelni wyższej. Często odbywa się to ze znaczącym udziałem stowarzyszeń zawodowych, nie tylko przeprowadzających egzaminy dopuszczające, lecz także stojących na straży przestrzegania reguł. Unijne rozumienie zawodu regulowanego zawiera art. 3 ust. 1a omawianej poniżej dyrektywy o uznawaniu. W tym ujęciu jest to działalność zawodowa lub ich zespół, których podjęcie i wykonywanie wymaga prawnie, bezpośrednio lub pośrednio, posiadania specjalnych kwalifikacji zawodowych, wiążąc się ponadto z używaniem zastrzeżonego tytułu zawodowego9.

Oczywiście to władze krajowe decydują nie tylko o systemie uzyskiwania kwalifikacji, lecz także o katalogu takich zawodów w ogóle, koncentrując się zwłaszcza na tych mających wpływ na życie i zdrowie czy szerzej — bezpieczeństwo obrotu. Dlatego też naturalny jest, znany także u nas, proces deregulacji niektórych z nich oraz sytuacja przybycia z kraju, w którym zawód nie należy do takiej kategorii, i zderzenia się z systemem regulowania określonej profesji. Dobrym przykładem podziału na dwie kategorie mogą być istotne w analizowanym kontekście zawody medyczne w Polsce, gdyż tylko niektóre z nich, jak lekarz czy diagnosta, mają charakter regulowany. $Z$ drugiej strony można wyliczyć znacznie większą grupę takich profesji, wobec których nie wypracowano transparentnego katalogu prawnych przesłanek wykonywania i nie narzucono odrębnych wymagań. Są to chociażby: dietetyk, logopeda, protetyk słuchu, psychoterapeuta i wielu techników — przykładowo dentystyczny czy farmaceutyczny ${ }^{10}$.

${ }^{8}$ L. Kortese, Exploring professional recognition in the EU: A legal perspective, „Journal of International Mobility" 1, 2016, nr 4, s. 43-58. Zob. też Penarroja, C-372/09 i 373/09, ECLI: EU:C:2009:637; omówienie uznawania dla celów akademickich zob. M. Górka, op. cit., s. 20-24.

${ }^{9} \mathrm{~K}$. Wojtczak, Zawód i jego prawna reglamentacja. Studium z zakresu materialnego prawa administracyjnego, Poznań 1999; M. Kożuch, Uznawanie kwalifikacji w Unii Europejskiej, Warszawa 2014, s. XIX-16-21; zob. też rozumienie zawodu regulowanego — Georgios Aranitis v. Land Berlin, C-164/94, ECLI:EU:C:1996:23.

${ }^{10}$ O. Kotowska, Deregulacja zawodów na przykładzie zawodu pracownika ochrony, „Przegląd Prawa Handlowego" 2016, nr 11, s. 47-58; R. Kręgulec, P. Pajorski, Ustawa o ochronie osób i mienia. Komentarz, Warszawa 2015, 165 n.; D. Karkowska, Zawody medyczne, Warszawa 2012, s. 221-229. 


\section{GENEZA I CHARAKTER REGULACJI}

Traktatową podstawę harmonizacji w omawianym zakresie stanowi obowiązujący od zarania wspólnotowego systemu traktatowego obecny art. 53 TFUE, który upoważnił Radę do przyjęcia dyrektyw zmierzających do wzajemnego uznawania do celów zawodowych dyplomów, świadectw i innych dokumentów potwierdzających posiadanie kwalifikacji. Został on co prawda umiejscowiony w ramach tylko jednej ze swobód osobowych — przedsiębiorczości, ale nie ma wątpliwości, że rozwiązania przyjmowane na tej podstawie znajdują pełne zastosowanie także w ramach świadczenia usług i przepływu pracowników ${ }^{11}$.

W ust. 2 tego artykułu wyraźnie przewidziano, że w odniesieniu do zawodów medycznych i paramedycznych oraz farmaceutycznych stopniowe znoszenie ograniczeń zależy od koordynacji warunków ich wykonywania w różnych państwach członkowskich. $Z$ tego też względu zawody te poddano regulacji jako pierwsze, już w latach siedemdziesiątych, przyjmując tak zwane dyrektywy „sektorowe”, harmonizujące właśnie wymogi kształcenia; to określenie trwale przylgnęło do tych profesji. Z jednej strony ułatwiało to dostęp do rynków innych państw, niemogących odmawiać już uznania kwalifikacji o analogicznej merytorycznie zawartości - tak powstał model automatyczny. Próby ponadnarodowej regulacji przy często odmiennych tradycjach okazały się jednak zadaniem karkołomnym, mimo że różnice były relatywnie niewielkie w porównaniu $\mathrm{z}$ innymi zawodami. Nawet legislacyjnie stanowiło to wyzwanie - przyjęto dwie uzupełniające się wzajemnie dyrektywy: wyznaczającą niezbędne wymogi kształcenia oraz wskazującą precyzyjnie kwalifikacje i dyplomy krajowe traktowane jako spełniające te wymagania ${ }^{12}$.

Taki charakter procesu harmonizacji implikował znaczne spowolnienie właściwie poza zawodami medycznymi próbowano nim objąć jedynie architektów, choć w skromniejszym wymiarze. Po ukonstytuowaniu w Unii w latach osiemdziesiątych nowego podejścia do harmonizacji rynku wewnętrznego postanowiono $\mathrm{z}$ tego zrezygnować na rzecz tak zwanego systemu ogólnego, który z wykorzystaniem niewielkiej liczby dyrektyw mógłby objąć wszystkie zawody wykonywane we wszelkich formach. Pierwszą była dyrektywa $89 / 48^{13}$ dotycząca zawodów wymagających wykształcenia wyższego, w wypadku których właśnie porzucono harmonizację wymogów kształcenia i tym samym także automatyczne uznawanie, co stało się unijnym wzorcem powielanym w kolejnych dyrektywach. Oczywiście na ich kształt niebagatelny wpływ miało rozbudowane orzecznictwo

${ }^{11}$ M. Szwarc-Kuczer, Komentarz do art. 53, [w:] Traktat o funkcjonowaniu Unii Europejskiej. Komentarz, t. 1. Art. 1-89, red. D. Miąsik, N. Półtorak, A. Wróbel, Warszawa 2012, s. 891-902; J. Osiejewicz, op. cit., s. 121-123.

${ }^{12}$ F. Weiss, F. Woolridge, Free Movement of Persons within the European Community, The Hague-London-New York 2002, s. 90.

${ }^{13}$ Dz.Urz. z 1989 r. L 19/16; Dz.Urz. PWS rozdz. 5, t. 1, s. 337. 
Trybunału Sprawiedliwości, które usankcjonowało wiele fundamentalnych reguł tego systemu, kodyfikowanych następnie w tych aktach ${ }^{14}$.

Ostatecznie w 2005 roku niemalże wszystkie przyjmowane akty o uznawaniu kwalifikacji — zarówno systemu ogólnego, jak i sektorowe, w liczbie 15 — zostały zastąpione jedną dyrektywą 2005/36/WE w sprawie uznawania kwalifikacji zawodowych (dalej: dyrektywa o uznawaniu) ${ }^{15}$. Nadal jednak istnieją zawody regulowane odrębnie, takie jak biegły rewident czy adwokat, aczkolwiek żadnego z nich nie objęto modelem automatycznym, co pozwala je pominąć w niniejszej analizie.

Dyrektywa o uznawaniu to obszerny i złożony dokument, który kompleksowo zmodernizował i uprościł cały system, konsolidując rozproszone regulacje, ale nie eliminując dotychczasowej odmienności modeli — ze względu na niesektorowy charakter określony jako przejaw harmonizacji horyzontalnej. Istotnym elementem jest wskazanie w tym dokumencie podstawowych zasad procedury, jakich należy przestrzegać w postępowaniach z wniosku o uznanie kwalifikacji zawodowych. W tych ramach mają poruszać się państwa członkowskie, gdy dostęp do zawodu regulowanego i jego wykonywanie w jakiekolwiek formie i w ramach każdej ze swobód rynku wewnętrznego uzależniają od posiadania kwalifikacji, jeżeli nie zostały one zdobyte lokalnie, ale w kraju pochodzenia umożliwiają analogiczną co do istoty działalność profesjonalną. Naczelną regułą jest wtedy zobowiązanie państwa przyjmującego do aktu uznania przyznającego na jego terytorium prawo do jego wykonywania zawodu na tych samych warunkach, jakie dotyczą miejscowych. Odbywa się to z zasady na podstawie takich dokumentów, jak dyplomy czy świadectwa ukończenia kształcenia zawodowego albo potwierdzające w inny sposób prawo do wykonywania profesji w kraju pochodzenia, które zgodnie $\mathrm{z}$ jego prawem wydały tam właściwe organy. $\mathrm{Z}$ tego względu akt ten nie zawsze musi potwierdzać, że zagraniczne przygotowanie jest nawet analogiczne i odnosić się do samoistnej wartości kształcenia, koncentrując się raczej na skutkach prawnych konkretnych dokumentów w miejscu ich wydania, a następnie wykorzystania, choć akurat w systemie automatycznym jest to konsekwencja harmonizacji dokonanej w tym zakresie ${ }^{16}$.

W strukturze dyrektywy 2005/36 wyodrębniono przede wszystkim swobody świadczenia usług w tytule II oraz przedsiębiorczości w tytule III, odwołując się do utrwalonego w systemie rynku wewnętrznego podziału, co oczywiście rozciąga się także na stałą aktywność pracowników. Ten ostatni, kluczowy tytuł w ko-

${ }^{14}$ M. Szwarz, op. cit., s. 102-103; E. Skibińska, op. cit., s. 45-66; D. Panagiotis, „Thou shall not... (dis)trust": Codes of conduct and harmonization of professional standards in the EU, „Common Market Law Review” 2010, nr 4, s. 1049-1087.

${ }^{15}$ Dyrektywa 2005/36/WE Parlamentu Europejskiego i Rady z dnia 7 września 2005 roku w sprawie uznawania kwalifikacji zawodowych (Dz.U. L 255 z 30.9.2005, s. 22-142, z późn. zm.), zaktualizowana dyrektywą 2013/55.

${ }^{16}$ S. Dudzik, Sposoby przeksztatcania prawa polskiego pod wplywem prawa europejskiego (na przyktadzie prawa gospodarczego), „Państwo i Prawo” 2008, nr 5, s. 3-19, tu: s. 9. 
lejnych rozdziałach wyodrębnia system ogólny oraz składające się właśnie na modele automatyczne uznawanie doświadczenia zawodowego, sektorową koordynację minimalnych wymogów kształcenia, co uzupełniono ostatnio wspólnymi ramami kształcenia. To tu właśnie przebiega główna linia podziału modeli uznawania i stopnia harmonizacji prawa krajowego, determinująca zarazem ów horyzontalny podział władzy. Natomiast tytuły I oraz IV określają przepisy ogólne oraz szczególne zasady wykonywania zawodu, takie jak niezbędna znajomość języków oraz prawo posługiwania się oryginalnymi tytułami określającymi wykształcenie. Wreszcie tytuł $\mathrm{V}$ reguluje zasady współpracy organów krajowych i wymiany informacji, łącznie z mechanizmem ostrzegania ${ }^{17}$.

Wdrożenie wskazanych rozwiązań w Polsce następuje głównie ustawą o zasadach uznawania kwalifikacji zawodowych nabytych w państwach członkowskich Unii Europejskiej (dalej: ustawa o uznawaniu), która bezpośrednio transponuje także zawarte $\mathrm{w}$ źródłowej dyrektywie definicje ${ }^{18}$. Zgodnie z jej art. 3 ustawę stosuje się do takiego uznawania, o ile przepisy odrębne nie stanowią inaczej, co ma znaczenie dla zawodów sektorowych. Jest to już trzeci akt prawny regulujący tę problematykę - poprzednio obowiązywała ustawa o analogicznym tytule z 2008 roku $^{19}$, a pierwotnie, od wejścia do UE, była to ustawa uchwalona jeszcze w $2001 \mathrm{roku}^{20}$.

Każdorazowo zapewniono tam, że jeżeli zawód jest regulowany w Polsce, to osoba, która uzyskała kwalifikacje dające prawo jego wykonywania w innym państwie członkowskim, może, a najczęściej musi, uzyskać ich oficjalne uznanie na podstawie tego dorobku. Obecna ustawa precyzuje procedury i właściwości organów — rozdział II reguluje zasady postępowania, począwszy od wymogów obowiązujących zainteresowanego, niezbędnych dokumentów, terminów oraz ostatecznych skutków jego przeprowadzenia, a więc prawa do wykonywania zawodu, posługiwania się polskim tytułem zawodowym oraz tytułem określającym wykształcenie z kraju pochodzenia. Dosyć precyzyjnie określono w art. 6 (oraz poprzez odesłanie do ustawy o działach administracji rządowej ${ }^{21}$ i przepisów regulacyjnych, jak też upoważnienie do wydawania rozporządzeń ministerialnych) właściwość organów. Również w Polsce, zwłaszcza w zawodach sektorowych, uznawanie kwalifikacji zalicza się do ustawowych zadań wielu organów samorządu, których rolę trudno przecenić — działają tu jako organy

${ }^{17}$ M. Pilich, Modernizacja dyrektywy o uznawaniu kwalifikacji zawodowych. Wnioski dla organizacji zawodowych oraz rzadowego procesu prac nad ustawa o zintegrowanym systemie kwalifikacji, [w:] Prawne aspekty..., s. 30.

${ }^{18}$ Ustawa z dnia 9 listopada 2018 roku o zasadach uznawania kwalifikacji zawodowych nabytych w państwach członkowskich Unii Europejskiej (tekst. jedn. Dz.U. poz. 2272).

19 Dz.U. z 2008 r. Nr 63, poz. 394.

${ }^{20}$ Ustawa z dnia 24 sierpnia 2001 roku o uznawaniu nabytych w państwach członkowskich Unii Europejskiej kwalifikacji do wykonywania zawodów regulowanych (Dz.U. Nr 87, poz. 954).

${ }^{21}$ Dz.U. z 2018 r. poz. 762 z późn. zm. 
administracji publicznej, podejmując czynności wykraczające poza wewnętrzne sprawy korporacyjne. Wzorem dyrektywy art. 29 ustawy o uznawaniu określił obowiązek znajomości języka polskiego ${ }^{22}$.

Uniwersalny charakter omawianej ustawy, odzwierciedlający zakres przedmiotowy dyrektywy o uznawaniu, powoduje, że w większości obowiązujących w Polsce ustaw dotyczących zawodów regulowanych zawarto po prostu odesłanie do jej przepisów w przedmiotowym zakresie, bez wprowadzania odrębnych procedur i wymogów materialnych. Natomiast wspomniane odesłanie do przepisów odrębnych w największym stopniu dotyczy zawodów sektorowych, w wypadku których nie podążono za unijnym prawodawcą i zrezygnowano ze scalenia aż na taką skalę. Przyjęto tu tradycyjną legislację, a więc kompleksowe unormowanie w osobnym akcie wszelkich aspektów uzyskania i wykonywania prawa zawodowego, łącznie z uznawaniem kwalifikacji. Wydaje się to uzasadnione, zważywszy na ów specyficzny model uznania, wymagający zwłaszcza norm szczególnych, określających odrębne dla każdej profesji i w znacznej liczbie konkretne dyplomy mające podlegać uznaniu ${ }^{23}$.

W ten sposób w każdej z ustaw, które nadal można określać mianem sektorowych, sprecyzowano same zasady postępowania oraz organy właściwe, a więc właśnie samorządy zawodowe, co implikuje obligatoryjne członkostwo jako warunek nabycia prawa do wykonywania zawodu. Są tam także przesłanki materialne i zasady uznania kwalifikacji oraz wymogi znajomości języka, jak też regulacje działalności przejściowej, w wypadku której klasyczne uznanie nie jest przeprowadzane. W jedynym wypadku tego rodzaju ustawa, określając jednolity wzór procedury, ale odmienne warunki, równocześnie sankcjonuje typowe uznawanie automatyczne, co dotyczy architektów, oraz opiera się na modelu ogólnym, w którym wobec inżynierów budownictwa odsyła się do ustawy o uznawaniu ${ }^{24}$. Ta ostatnia znajdzie zresztą zastosowanie także u każdego przedstawiciela zawodów sektorowych, który nie spełnia warunków automatycznego uznania. Pozostałe ustawy sektorowe są już tylko medyczne - lekarz i lekarz dentysta ${ }^{25}$, pielęgniarka i położna ${ }^{26}$, far-

${ }^{22}$ M. Kożuch, op. cit., s. XIX-97; I. Kawka, op. cit., s. 324-328; A. Bochentyn, P. Glejt, M. Miłosz, Przeglad orzecznictwa sadowego w zakresie spraw administracyjnych rozstrzyganych $w$ drodze decyzji administracyjnej przez podmioty spoza struktury państwa i samorzadu terytorialnego, „Gdańskie Studia Prawnicze - Przegląd Orzecznictwa” 2014, nr 1, s. 23; W. Dzierżanowski, Ochrona konkurencji w prawie zamówień publicznych, Warszawa 2012, s. 266-270.

23 A. Despot-Mładanowicz, Komentarz do art. 12a, [w:] Prawo budowlane. Komentarz aktualizowany, red. A. Plucińska-Filipowicz, M. Wierzbowski, LEX/el. 2019.

${ }^{24}$ Ustawa o samorządach zawodowych architektów i inżynierów budownictwa (tekst jedn. Dz.U. z 2019 r. poz. 111).

${ }^{25}$ Ustawa o zawodach lekarza i lekarza dentysty (tekst jedn. Dz.U. z 2019 r. poz. 537).

${ }^{26}$ Ustawa o zawodach pielęgniarki i położnej (tekst jedn. Dz.U. z 2019 r. poz. 576). 
maceuta ${ }^{27}$ oraz lekarz weterynarii, wobec którego wyjątkowo nie przewidziano możliwości działalności przejściowej28.

\section{KONKRETYZACJA MODELI}

Przyjęcie przedstawionych rozwiązań uniemożliwiło uzależnianie przez władze krajowe wykonywania zawodów regulowanych od nabycia kwalifikacji w macierzystym systemie oraz uczynienia jedynym akceptowanym wymogiem formalnym czy też dowodem w postepowaniu o przyznanie takiego prawa dokumentów wydanych przez siebie. Natomiast to w modelach automatycznych harmonizacja mogła posunąć się najdalej, pozbawiając ich władze możliwości weryfikacji wiedzy i umiejętności, a nawet ingerując w systemy kształcenia. Ten ostatni aspekt dotknął głównie, szczególnie ważne dla gospodarki, zawody sektorowe, ale warto też zwrócić uwagę na przypadki bardziej ograniczonej regulacji, a zwłaszcza uznawanie doświadczenia zawodowego. Dlatego wydaje się to interesujące, determinując zakres kompetencji do dopuszczania do zawodu czy też ogólniej autonomicznego regulowania rynku działalności profesjonalnej29.

\subsection{TRADYCYJNE ZAWODY SEKTOROWE}

Jak już wskazywano, to od zawodów medycznych rozpoczął się proces harmonizacji zasad uznawalności i to właśnie w tym zakresie starano się praktykować tradycyjne podejście, polegające na ustalaniu wspólnych wymogów kształcenia czyniących dyplomy porównywalnymi. O ile konieczność uzgodnienia programów nauczania obowiązujących wszystkie krajowe uczelnie spowodowała odejście od tego modelu w dominującej większości profesji, to ów dorobek sektorowy zachowano także w dyrektywie o uznawaniu, co ze względu na automatyzm uznawania samych dyplomów czyni je ważnym systemowo elementem. Dzieje się tak pomimo ich ograniczonego, wyliczonego już katalogu, który wraz z przyjęciem tej dyrektywy nie uległ i z pewnością już nie ulegnie zmianie, tym bardziej że stworzono omawianą dalej alternatywę w postaci wspólnych ram kształcenia ${ }^{30}$.

Nie należy przez to rozumieć, że treści kształcenia są w każdym państwie identyczne, gdyż mają one raczej charakter minimów programowych wynegocjowanych w unijnym procesie legislacyjnym. Wystarcza to jednak, aby osoba wyedukowana zgodnie z prawem jednego państwa, implementującym zharmonizowane wymogi, była w pozostałych uznawana za w pełni wykształconego

${ }^{27}$ Ustawa o izbach aptekarskich (tekst jedn. Dz.U. z 2019 r. poz. 1419).

${ }^{28}$ Ustawa o zawodzie lekarza weterynarii i izbach lekarsko-weterynaryjnych (tekst jedn. Dz.U. z 2019 r. poz. 1140).

${ }^{29}$ R. Janas, op. cit., s. 924; M. Kożuch, op. cit., s. XIX-50.

${ }^{30}$ M. Kożuch, op. cit., s. XIX-73 n. 
i w efekcie uprawnionego lekarza, farmaceutę itp. Dlatego właśnie ukończenie gdziekolwiek w Unii zadekretowanego ponadnarodowo cyklu kształcenia skutkuje obowiązkiem automatycznego uznania we wszystkich państwach, pozbawiając władze państwa członkowskiego dyskrecji i możliwości egzekwowania jakichkolwiek własnych wymogów i dodatkowych kwalifikacji, zwłaszcza nieznajdujących pokrycia w dyrektywie, takich jak weryfikacji wiedzy i umiejętności ${ }^{31}$.

Skoro w tym modelu rozumiany funkcjonalnie „dyplom”, potwierdzający czasem obok ukończenia studiów na przykład także zdanie egzaminu zawodowego, opiewa na w zasadzie analogiczną zawartość i rodzi takie same skutki, to sama procedura uznawalności ma specyficzny wymiar. Koncentruje się ona na zweryfikowaniu posiadania jednego z takich konkretnych dokumentów wydanych przez właściwy organ krajowy, wymienionych wyraźnie na wyczerpującej liście, której stworzenie na podstawie zgłoszeń państw i załączenie do dyrektywy o uznawaniu stało się puntem wyjścia. Na podstawie przewidzianego w jej art. 21 zobowiązania nałożonego na państwa to właśnie zapewnia uznanie i uprawnia do wykonywania zawodu na ich terytorium w danym zakresie zastrzeżonych czynności, w formie świadczenia pracy, okazjonalnych usług lub działalności na własny rachunek, chociażby w postaci gabinetu. Natomiast kraj macierzysty bierze odpowiedzialność za wydanie dyplomu oraz za to, że potwierdza on spełnienie owych minimalnych wymogów określonych w treści tego aktu dosyć szczegółowo i odrębnie dla każdego z zawodów sektorowych.

W wypadku lekarzy wyodrębniono nawet podstawowe kształcenie medyczne, specjalistyczne oraz osobno profesję lekarza medycyny ogólnej. Na tym pierwszym poziomie określono długość kształcenia teoretycznego i praktycznego, model (uniwersytecki i kliniczny) oraz charakter i ogólny przedmiot wymaganej wiedzy. Harmonizacja kształcenia w ramach specjalizacji doprowadziła natomiast do stworzenia ich listy w liczbie ponad $50-$ z tytułami uznanymi w całej Unii. Dla pozostałych zawodów medycznych ustalono nie tylko okres i wymogi co do sposobu takiego kształcenia oraz uzyskanej wiedzy, umiejętności i kompetencji, lecz także bardziej lub mniej precyzyjnie określone programy, przewidując ich uaktualnianie wraz z postępem technicznym i naukowym. W części z nich (położna, farmaceuta) jasno wskazano wspólny zakres zastrzeżonych czynności zawodowych.

Na tym tle regulacje dotyczące architektów są bardziej ograniczone, pozostawiają państwom większą swobodę, ale są obecnie oparte na zbliżonym modelu. Ten zawód przeszedł jednak największą ewolucję regulacyjną, gdyż pierwotnie nie było minimów, a państwa zobowiązały tylko się zagwarantować właściwy, acz niezharmonizowany poziom. Dlatego też w tych ramach przewidziano najdłuższą listę historycznych dyplomów potwierdzających posiadanie kwalifikacji.

System uzupełnia wiele bardzo szczegółowych norm o ochronie praw nabytych, z których warunkowo mogą korzystać pewni specjaliści wykwalifikowani

31 M. Górka, op. cit., s. 32. 
niezgodnie ze zharmonizowanymi wymogami. $Z$ zasady pochodzą oni z nowych państw członkowskich, wykazując się często długim stażem zawodowym, ale kwalifikacjami zdobytymi zanim ich macierzyste systemy zostały do tego dostosowane. $Z$ jednej strony są to pewne normy wspólne dla wszystkich państw i zawodów, z wyłączeniem architekta, zawarte $\mathrm{w}$ art. 23 , w wypadku których istotną rolę odgrywa uzupełnienie wykształcenia faktycznym i legalnym wykonywaniem danej działalności przez pewien czas. Ponadto dyrektywa zawiera rozwiązania szczególne, odrębne dla poszczególnych państw, oraz pewne gwarancje w ramach konkretnych zawodów, jak na przykład lekarzy specjalistów czy polskich pielęgniarek ${ }^{32}$.

Wdrożenie omówionych rozwiązań w Polsce nastąpiło, jak już wskazano, w odrębnych ustawach regulujących poszczególne zawody. Dlatego też ustawa o izbach aptekarskich, określając, kto posiada kwalifikacje do wykonywania zawodu farmaceuty, wobec osób pochodzących z innych państw członkowskich $\mathrm{w}$ art. $2 \mathrm{~b}$ przewiduje konieczność ukończenia kształcenia spełniającego wymagania unijne, potwierdzonego dokumentami uznanymi za równoważne z polskim magistrem farmacji, których wykaz na podstawie upoważnienia ustawowego ogłasza minister zdrowia na drodze obwieszczenia ${ }^{33}$. Podobne rozwiązanie przewidziano w art. 5 ust. 1 pkt 2c ustawy „lekarskiej”, co jest o tyle istotne, że posiadacz takiego zagranicznego dyplomu nie ma obowiązku (ciążącego na polskich absolwentach) odbycia stażu podyplomowego i zdania Lekarskiego lub Lekarsko-Dentystycznego Egzaminu Państwowego, nawet jeżeli w kraju pochodzenia nie ma ich ekwiwalentów ${ }^{34}$. Odpowiednio kwestie uznania reguluje art. 2 ust. 1 pkt 2b w ustawie dotyczącej weterynarzy, art. 33a aktu prawnego dotyczącego architektów ${ }^{35}$ oraz art. 28-32 ustawy o zawodach pielęgniarki i położnej ${ }^{36}$.

Uzupełniająco, zwłaszcza w zawodach medycznych, istnieje możliwość przedstawienia dyplomu niemieszczącego się we wskazanym zakresie, jeżeli władze macierzyste potwierdzą, że kwalifikacje uzyskano po odbyciu kształcenia zgodnego ze standardami unijnymi (w wypadku położnych pod dodatkowymi

${ }^{32}$ M. van Riemsdijk, Obstacles to the free movement of professionals: Mutual recognition of professional qualifications in the European Union, „European Journal of Migration and Law” 15, 2013, s. 47-68.

${ }_{33}$ M. Kwiatkowska, Prawo farmaceutyczne dla aptek, cz. 1, Warszawa 2017.

${ }^{34}$ K. Majcher, Komentarz, [w:] Ustawa o zawodach lekarza i lekarza dentysty, red. E. Zielińska, Warszawa 2014, s. 145 n.; L. Ogiegło, Ustawa o zawodach lekarza i lekarza dentysty. Komentarz, wyd. 2, Warszawa 2015, komentarz do art. 5, s. 18 n.; Z. Góral, Zatrudnianie cudzoziemców, Warszawa 2015, s. 250-260; A. Plichta, Ustawa o zawodach lekarza i lekarza dentysty. Komentarz, Warszawa 2016, s. 657 n.

${ }^{35}$ W. Hartung, G. Wicik, Uznawanie kwalifikacji zawodowych architektów i inżynierów nabytych w państwach członkowskich UE a zamówienia publiczne, „Prawo Zamówień Publicznych” 2008, nr 3, passim; A. Gliniecki, Prawo budowlane. Komentarz, wyd. 3, Warszawa 2016, s. 173-177.

${ }^{36}$ D. Karkowska, W.C. Włodarczyk, Prawo medyczne dla pielegniarek, Warszawa 2013, s. 90-92; M. Sadowska, Komentarz, [w:] Ustawa o zawodach pielęgniarki i położnej. Komentarz, red. W. Lis, M. Sadowska, Warszawa 2019, s. 210-212. 
warunkami). Osobno implementowano rozbudowane zasady ochrony praw nabytych ze wskazaniem konkretnych przypadków dla każdego państwa. Tu posiadanie dyplomu niespełniającego wymogów wiąże się z rekompensatą dodatkowym stażem zawodowym, pod rygorem nałożenia w Polsce środków wyrównawczych przewidzianych w systemie ogólnym.

\subsection{WSPÓLNE RAMY KSZTAŁCENIA}

O ile tradycyjny system sektorowy nie wydaje się możliwy do rozszerzania na inne zawody regulowane, o tyle idea pewnej harmonizacji wymuszającej bardziej bezwarunkowe uznawanie, istotnie ułatwiające przepływ profesjonalistów w Unii, nie została całkowicie zarzucona. Ostatnia nowelizacja dyrektywy o uznawaniu, wprowadzając art. 49a i 49b, przyjęła jednak postać ograniczoną i elastyczną, co bardziej odpowiada aktualnemu podejściu do ponadnarodowej regulacji. Zamiast na tym poziomie określać minimalne wymogi, zaprojektowano możliwość wypracowywania nawet przez grupę państw (minimum jedną trzecią) tak zwanych wspólnych ram dotyczących wykształcenia, opartych na uzgodnionym minimalnym zasobie wiedzy, umiejętności i kompetencji oraz uznanym za niezbędny do wykonywania określonego zawodu.

Nie muszą one zastępować narodowych programów, a dodatkowo dyrektywa dopuszcza pewną możliwość zwolnienia państw od ich wprowadzenia na swoim terytorium. Natomiast w zawodach, w których uda się je ustanowić, wszyscy obywatele UE powinni mieć taką możliwość, aby opierając się na tych ramach, uzyskiwać kwalifikacje z zagwarantowaną automatyczną uznawalnością. Ponownie więc wystarczy legitymowanie się stosownym dokumentem zgodności ze wspólnymi ramami, gdyż potwierdza on, że kwalifikacje należy traktować jako dostateczne do wykonywania zawodu. Jest to więc dalej idący skutek niż w wypadku posiadania zwykłego dyplomu z innego państwa, potwierdzającego tamtejsze prawo zawodowe, jeżeli nie jest to obszar sektorowy — bez możliwości egzekwowania środków wyrównawczych, względnie wymogów dodatkowych, nawet jeżeli są one praktykowane $\mathrm{w}$ danym systemie krajowym. Uzupełnieniem jest możliwość stworzenia wspólnego ustandaryzowanego testu umiejętności, weryfikującego określone kwalifikacje zawodowe ${ }^{37}$.

Implementując wskazane regulacje, ustawa o uznawaniu zdefiniowała w art. 5 wspólne ramy i test. Natomiast art. 30 gwarantuje, że wobec osób legitymujących się dokumentami wydanymi zgodnie $\mathrm{z}$ wskazanymi zasadami nie przeprowadza się postępowania w sprawie uznania kwalifikacji, gdyż stanowią one samoistną podstawę do wydania decyzji w sprawie wykonywania zawodu regulowanego. Upoważniono ponadto ministra ds. szkolnictwa wyższego i nauki do określenia wykazu takich wspólnych reżimów wraz z przyporządkowanymi im polskimi kwalifikacja-

${ }^{37}$ M. Pilich, op. cit., s. 32. 
mi, biorąc jednak pod uwagę między innymi konieczność eliminacji poważnego ryzyka dla porządku, bezpieczeństwa i zdrowia publicznego, jak też bezpieczeństwa usługobiorców lub ochrony środowiska, jakie mogłyby one wywołać.

\subsection{UZNAWANIE DOŚWIADCZENIA ZAWODOWEGO}

W obecnym systemie unijnym wyodrębnić można jeszcze jeden przypadek automatycznego uznawania, właściwie bez kompetencji państwa przyjmującego do weryfikacji zawartości zdobytego przygotowania zawodowego, ale też bez jego harmonizacji.

Rozdział II tytułu III dyrektywy o uznawaniu przewiduje bowiem przyznanie prawa do wykonywania różnych zawodów, głównie technicznych, w określonych aktywnościach, podzielonych na trzy wiodące kategorie: przemysłowe (na przykład branża włókiennicza, naftowa, produkcja budowlana); transport, telekomunikacja i usługi osobiste; różne inne sektory, jak wynajmem, restauracje i hotele, a nawet niektóre profesje z zakresu bankowości i finansów. W tych obszarach uznaje się doświadczenie zawodowe $\mathrm{z}$ innego państwa członkowskiego za samoistną podstawę do przyznania prawa do wykonywania zawodu regulowanego. Dowodu nie ma stanowić dyplom lub analogiczny dokument, tylko potwierdzenie uprzedniego wykonywania danego zawodu w innych państwach, na warunkach określonych $\mathrm{w}$ dyrektywie, a więc $\mathrm{z}$ uwzględnieniem okresu trwania oraz form zdobywania takiego doświadczenia w danym sektorze. W zależności od przynależności do jednej z tych kategorii różną wagę nadaje się kombinacjom stażu oraz charakteru aktywności - na własny rachunek, na stanowisku kierownika przedsiębiorstwa, a nawet pracy najemnej. Uprzednie kształcenie zawodowe nie jest tutaj determinantą, ale może zredukować zakres wymaganego doświadczenia ${ }^{38}$.

Omówione rozwiązania zostały wdrożone art. 16 ustawy o uznawaniu. Przewiduje on, że jeżeli dostęp do danej działalności jest uzależniony od posiadania wiedzy ogólnej lub zawodowej i właściwych umiejętności, należy uznać kwalifikacje zawodowe wnioskodawcy, który przedłoży dokumenty świadczące o jej wykonywaniu. W tym zakresie, w kolejnych trzech artykułach, powiązanych z wzorującymi się na dyrektywie wykazami zawartymi w załączniku IV do ustawy, określającymi rodzaje działalności, w sposób zróżnicowany sprecyzowano warunki takiego uznania. Na tej podstawie także odpowiedni ministrowie mogą wydawać stosowne rozporządzenia konkretyzujące przesłanki uznawania praktyki zawodowej39.

38 I. Kawka, op. cit., s. 309.

${ }^{39}$ Zob. np. rozporządzenie Ministra Kultury i Dziedzictwa Narodowego w sprawie uznawania praktyki zawodowej do wykonywania zawodów konserwatora zabytków ruchomych, konserwatora zabytków nieruchomych, konserwatora zabytkowej zieleni oraz archeologa (Dz.U. z 2016 r. poz. 414) oraz rozporządzenie Ministra Zdrowia w sprawie uznawania praktyki zawodowej odbytej przez technika farmaceutycznego (Dz.U. z 2016 r. poz. 816). 


\title{
MODELS OF AUTOMATIC RECOGNITION OF PROFESSIONAL QUALIFICATIONS IN THE EUROPEAN UNION AND THEIR IMPLEMENTATION IN THE POLISH LEGAL ORDER
}

\author{
Summary
}

The aim of the article is analysis of the application of regulatory mutual recognition in the special area of recognition of professional qualifications in the European Union - both at supranational and national levels. It may present more general rules of the functioning of the single internal market and its freedoms, especially personal ones, i.e. the separation of powers between Members States regulatory regimes themselves - host and home ones as well as between Member States and the Union. One model of recognition was selected for this purpose - automatic — as the most far-reaching example of regulatory interference at supranational level. The analysis focused on understanding recognition in the framework of regulated professions and systematics of legal acts of European Union law and Polish legal system as an example of national implementing efforts. Particular emphasis was put on presenting the special nature of recognition in medical professions as well as minimum training conditions and recognition of professional experience.

Keywords: principle of mutual recognition, recognition of professional qualifications, directive 2005/36, sectorial professions, minimum training conditions

\section{BIBLIOGRAFIA}

Armstrong K.A., Mutual recognition, [w:] The Law of the Single European Market. Unpacking the Premises, red. C. Barnard, J. Scott, Hart 2002.

Blitz B., Professional mobility and the mutual recognition of qualifications in the European Union: Two institutional approaches, „Comparative Education Review” 1999, $\mathrm{nr} 43$.

Bochentyn A., Glejt P., Miłosz M., Przeglad orzecznictwa sądowego w zakresie spraw administracyjnych rozstrzyganych $w$ drodze decyzji administracyjnej przez podmioty spoza struktury państwa i samorządu terytorialnego, „Gdańskie Studia Prawnicze — Przegląd Orzecznictwa” 2014, nr 1.

Despot-Mładanowicz A., Komentarz do art. 12a, [w:] Prawo budowlane. Komentarz aktualizowany, red. A. Plucińska-Filipowicz, M. Wierzbowski, LEX/el. 2019.

Dudzik S., Sposoby przeksztatcania prawa polskiego pod wptywem prawa europejskiego (na przyktadzie prawa gospodarczego), „Państwo i Prawo” 2008, nr 5.

Dzierżanowski W., Ochrona konkurencji w prawie zamówień publicznych, Warszawa 2012.

Gliniecki A., Prawo budowlane. Komentarz, wyd. 3, Warszawa 2016.

Góral Z., Zatrudnianie cudzoziemców, Warszawa 2015.

Górka M., Zasada wzajemnego uznawania w prawie Unii Europejskiej, Warszawa 2014.

Hartung W., Wicik G., Uznawanie kwalifikacji zawodowych architektów i inżynierów nabytych w państwach członkowskich UE a zamówienia publiczne, „Prawo Zamówień Publicznych” 2008, $\mathrm{nr} 3$.

Janas R., Wzajemne uznawanie dyplomów, [w:] Unia Europejska. Prawo instytucjonalne i gospodarcze, red. A. Łazowski, Warszawa 2007.

Karkowska D., Zawody medyczne, Warszawa 2012.

Karkowska D., Włodarczyk W.C., Prawo medyczne dla pielęgniarek, Warszawa 2013.

Kawka I., Gospodarcza działalność usługowa w prawie polskim w świetle unijnych swobód przedsiębiorczości i świadczenia ustug, Warszawa 2015. 
Kortese L., Exploring professional recognition in the EU: A legal perspective, „Journal of International Mobility" 1, 2016, $\mathrm{nr} 4$.

Kotowska O., Deregulacja zawodów na przykładzie zawodu pracownika ochrony, „Przegląd Prawa Handlowego" 2016, nr 11.

Kożuch M., Uznawanie kwalifikacji w Unii Europejskiej, Warszawa 2014.

Kręgulec R., Pajorski P., Ustawa o ochronie osób i mienia. Komentarz, Warszawa 2015.

Kwiatkowska M., Prawo farmaceutyczne dla aptek, cz. 1, Warszawa 2017.

Majcher K., Komentarz, [w:] Ustawa o zawodach lekarza i lekarza dentysty, red. E. Zielińska, Warszawa 2014.

Möstl M., Preconditions and limits of mutual recognition, „Common Market Law Review” 2010, $\mathrm{nr} 2$.

Nicolaïdis K., Globalization with human faces: Managed mutual recognition and the free movement of professionals, [w:] The Principle of Mutual Recognition in the European Integration Process, red. F. Kostoris Padoa-Schioppa, Rome 2005.

Ogiegło L., Ustawa o zawodach lekarza i lekarza dentysty. Komentarz, wyd. 2, Warszawa 2015.

Osiejewicz J., Harmonizacja prawa państw członkowskich Unii Europejskiej, Warszawa 2016.

Panagiotis D., ,"Thou shall not...(dis)trust”: Codes of conduct and harmonization of professional standards in the EU, „Common Market Law Review” 2010, nr 4.

Pilich M., Modernizacja dyrektywy o uznawaniu kwalifikacji zawodowych. Wnioski dla organizacji zawodowych oraz rzadowego procesu prac nad ustawa o zintegrowanym systemie kwalifikacji, [w:] Prawne aspekty porównywania i uznawania kwalifikacji w Unii Europejskiej, red. M Ponikowska, Warszawa 2015.

Plichta A., Ustawa o zawodach lekarza i lekarza dentysty. Komentarz, Warszawa 2016.

Riemsdijk M. van, Obstacles to the free movement of professionals: Mutual recognition of professional qualifications in the European Union, „European Journal of Migration and Law” 15, 2013.

Sadowska M., Komentarz, [w:] Ustawa o zawodach pielęgniarki i położnej. Komentarz, red. W. Lis, M. Sadowska, Warszawa 2019.

Skibińska E., Analiza orzecznictwa Trybunału Sprawiedliwości Unii Europejskiej dotyczacego wzajemnego uznawania dyplomów, świadectw i innych dokumentów potwierdzających posiadane kwalifikacje, [w:] Prawne aspekty porównywania i uznawania kwalifikacji w Unii Europejskiej, red. M. Ponikowska, Warszawa 2015.

Skrzydło-Tefelska E., Swobodny przepływ osób a wykonywanie zawodu w Unii Europejskiej, „Rejent" 2000, nr 10.

Slot P.J., Harmonisation, „European Law Review” 1996, nr 5.

Szwarc M., Modele regulacji rynku wewnętrznego — integracja negatywna i pozytywna, [w:] System Prawa Unii Europejskiej, t. 7. Prawo rynku wewnętrznego, red. D. Kornobis-Romanowska, Warszawa 2020.

Szwarc-Kuczer M., Komentarz do art. 53, [w:] Traktat o funkcjonowaniu Unii Europejskiej. Komentarz, t. 1. Art. 1-89, red. D. Miąsik, N. Półtorak, A. Wróbel, Warszawa 2012.

Torres R., The European recognition of professional qualifications - a legal framework for the European citizenship, „EU Law Journal” 2, 2016, nr 2.

Ustawa o zawodach lekarza i lekarza dentysty, red. E. Zielińska, Warszawa 2014.

Weatherill R., Pre-emption, harmonisation and the distribution of competence to regulate the internal market, [w:] The Law of the Single European Market. Unpacking the Premises, red. C. Barnard, J. Scott, Hart 2002.

Wojtczak K., Zawód i jego prawna reglamentacja. Studium z zakresu materialnego prawa administracyjnego, Poznań 1999.

Weiss F., Woolridge F., Free Movement of Persons within the European Community, The Hague-London-New York 2002.

Przegląd Prawa i Administracji CXX, 2020, cz. 1 i 2

(C) for this edition by CNS 